\title{
ENZYME PROFILE OF AQUATIC HYPHOMYCETES ISOLATED FROM THE STREAMS OF KODAGU DISTRICT OF KARNATAKA
}

\author{
Dr. Soosamma:M.*, \\ Jayarani, J.A; Sophia,M.R; P.oornima, ; Suchismitha,C; and Rashmi,R.
}

\begin{abstract}
Aquatic hypomycetes, isolated from the streams of Bloomfields, Somwarpet of Kodagu district, are capable of secreting an array of wall degrading enzyme, which transform the leaf litter into more palatable food for the detrivores. The objectives of the present study was to check the ability of these fungi in producing wafl degrading enzymes invitro. Only two of the fungi namely Acremonium sps. and a non sporulating unidentified white colony producing $\mathrm{sps}$, were used for the Present study. These were grown on media containing cellulose, starch and pectin as substrate and their ability to produce cellulose, anylase, invertase and pectinase studied. Depending upon the availability of the substrate these fungi were able to produce varying conc. of enzymes. It was very intresting to note that the non-sporulating sps. showed a nine fold increase in pectinase production compared to Acremonium sps.
\end{abstract}

\section{Introduction}

The major natural habitat of aquatic hyphomycetes appear to be the submerged decaying leaves of dicotyledonous plants. Leaves begin to shed in summer and find their way into streams and rivers, but the main leaf fall is in October. Probably as a consequence, these fungi reach their richest development in the last three or four months of the year. These fungi can be found throughout, but the Autumn months are recommended. Aquatic hyphomycetes are filamentous and mostly moniliaceous, conidia forming fungi. Their conidia are characteristically

*Reader, Department of Botany, Mount Carmel College, Bangalore, 560 052, India. 
shaped-They are tetraradiate, sigmoid, coiled etc and often appendaged. Aquatic hyphomycetes bring about the degradation of leaf litter as they secrete wall degrading enzymes. Among the micro organisms aquatic hyphomycetes are the most active in degrading leaf tissue in a stream, (Kaushik and Hynes, 1917; Kostlos and Seymour, 197.6; Barlocher and Kendrick, 1981), thus transforming the leaf litter into a more palatable food for the detrivores.

The present study deals with the collection, aeration, isolation and identification of aquatic hyphomycetes based on type of spores followed by the study of wall degrading enzyme secreted by them invitro. Nine sps. of aquatic hyphomycetes were isolated, of which two species Acremonium sps. and a non-sporulating white colony producing fungi was used to study the enzyme profile.

\section{Materials and Methods}

Collection of leaf litter was preferably done from clean tree lined streams that are fast flowing with occasional rapids. Leaves are best gathered individually from the bed of the stream. Dark brown leaves that are softened and partially skeletonised are collected from the streams and used as samples, 5-10 such leaves or twigs are collected, rinsed in water and placed in clean fresh polythene bags and are labelled and transported in an ice pack container to the laboratory.

\section{Aeration}

Each leaf is placed in a clean wide mouth bottle with distilied water at room temperature for two to several days and a jet of air using an aquarium aerator is passed through to hasten sporulation. A drop of detergent is added to this water and shaken well. Spores that are floating get caught in the foam. The foam is scooped out onto a slide and is examined under a microscope. When the foam settled a collection of spores can be seen when the slide is dried and stained.

\section{Isolation}

In order to isolate the spores from the aerated litter and obtain a single spore culture the following method was employed:

1. The aeration was increased and foam scooped out with a clean slide.

2. After focussing the slide under the microscope single spores can be picked up with a help of a pointed needle.

3. The spores are then transferred onto PDA Petri plates. 


\section{Maintenance of Pure Culture}

Cultures were maintained on PDA slants to which an antibiotic was added. The slants were maintained in a refrigerator at $10^{\circ} \mathrm{C}$ and sub-cultured every three months.

\section{Sporulation}

Generally freshwater hyphomycetes do not sporulate above water (Ingold, 1975). Therefore one cannot expect a sporulating colony in the media. However, in order to identify the isolate, the fungus was induced to sporulate. All freshwater hyphomycetes sporulate readily as soon as they get back to water. This was done as follows.

1. A strip of pure agar culture was cut and submerged in sterile distilled water under aseptic conditions.

2. In a few days conidia developed. In case conidia do not develop a stream of air has to be sent from a "fish aerator" and after several hours spores can be noticed emerging out from the fungal colony submerged in water.

\section{Study of wall degrading enzymes invitro}

In fungi many enzymes are known, whose appearance is dependent upon the presence of a substrate. These enzymes which are secreted make the insoluble substance available for growth by cleavage of complex organic compounds. Acremonium sps. and the non-sporulating white cottony colony forming fungi were capable of producing cellulase, pectinase, amylase, invertase and pectin trans - eliminase.

\section{Media used to induce enzyme production}

Three different liquid media were used to induce enzyme production Asparagine glucose pectin medium, Czepek dox medium with $1 \%$ cellulose, Czepek dox medium with $1 \%$ starch. $100 \mathrm{ml}$ of liquid medium was dispensed into $250 \mathrm{ml}$ conical flasks. Flasks were plugged with cotton wool and capped with aluminium foil and autoclaved for 15 mins. at $120^{\circ} \mathrm{C}$.

\section{Inoculation}

Each of the flasks was inoculated with one disc of $1 \mathrm{~cm}$ diameter of agar with the mycelium from Petri plates using a sterile cork borer. One flask containing a disc of PDA served as control. 


\section{Enzyme Source}

The inoculated flasks were incubated at room temperature. Cultures were harvested every third day till the tenth day and thereafter every alternate day till the twentieth day. Cultures were harvested by filtering through pre-weighed Whatmann filter paper discs using suction. The resulting filtrate served as the enzyme source. Enzymes were stored at $4^{\circ} \mathrm{C}$ till further use.

\section{Growth and mycelial mat weight}

The filter paper along with the mycelium was dried at $50^{\circ} \mathrm{C}$ for $2-3$ days and weighed everyday till the weight was stable.

\section{Proteins}

Proteins were estimated by the method of Lowry et al, 1951, using BSA as standard. Samples were taken in duplicates.

\section{Pectinase activity}

Was measured by Viscometer method using $0.5 \%$ Pectin in Tris $-\mathrm{HCl}$ buffer $\mathrm{pH} 8.7$, as substrate containing $0.2 \mathrm{M} \mathrm{CaCl}$ and incubated at $34+/-1^{\circ} \mathrm{C}$. Pectinase activity was calculated as follows:-

$$
\text { To-T1 } \times 100
$$

$$
\text { To }-\mathrm{Tw}
$$

Where $\mathrm{To}=$ flow time in seconds ( zero time)

$T 1$ = flow time of reaction mixture at time $T$

$T_{w}=$ flow time of distilled water.

\section{Pectin Trans-eliminase}

Assay was by the spectrophotometric method using $0.5 \%$ Pectin and $\mathrm{CaCl}_{2}$ and incubated at $34+1-1^{\circ} \mathrm{C}$ for 1 hour. The OD was read at $550 \mathrm{~nm}$.

\section{Cellulase}

Was assayed by the Viscometric method using $0.5 \%$ Carboxy methyl cellulose in $0.2 \mathrm{M}$ Sodium Acetate buffer $\mathrm{pH} 5.2$ and incubated at $44+/-1^{\circ} \mathrm{C}$. Cellulase activity was calculated as for Pectinase. 


\section{Amylase}

Reaction mixture contained $1 \%$ soluble starch, Sodium acetate buffer and enzyme, this was incubated at $37^{\circ} \mathrm{C}$ for 24 hours. Reducing sugars released was measured using DNS reagent and absorbance read at $575 \mathrm{~nm}$.

\section{Invertase}

Reaction mixture contained $2.5 \%$ sucrose. Reducing sugars released was measured at $575 \mathrm{~nm}$ using glucose as standard.

\section{$\mathrm{pH}$}

$\mathrm{pH}$ of the culture filtrate was measured using a $\mathrm{pH}$ meter.

\section{Results}

Acremonium sps. and the non - sporulating white colony producing fungi in this study produced Pectinase, Pectin transeliminase, Cellulase, Amylase, and Invertase. The peak activity of pectinase by Acremonium sps. was on the $14^{\text {th }}$ day and that of the non - sporulating white colony producer was on the $19^{\text {th }}$ day (fig.1\&2).

It was interesting to note that the non-sporulating fungi showed a ninefold increase in pectinase activity when compared to Acremonium sps. PTE was maximum on the $15^{\text {th }}$ day with Acremonium sps. and on the $21^{\text {st }}$ day with the non-sporulating white colony producer (fig. $3 \& 4$ ). Amylase and Invertase production was on the $15^{\text {th }}$ and $12^{\text {th }}$ day for Acremonium sps. (fig. 5\&6) and in the case of non-sporulating white colony producer the maximum activitywas on the $17^{\text {th }}$ and $11^{\text {th }}$ day (fig. 7\&8).

Cellulase activity was maximum on the $18^{\text {th }}$ day for Acremonium sps. and $16^{\text {th }}$ day for the non-sporulating sps. (fig. 9\&10). During cellulase production, the $\mathrm{pH}$ became basic and later acidic with the non-sporulating sps. (fig. 11). With Acremonium sps. the $\mathrm{pH}$ turned acidic during pectinase production (fig. 12). The protein concentration was maximum on the $14^{\text {th }}$ and16th day for the fungi with cellulose medium (fig. 13\&14), whereas with pectin medium maximum protein was on the $15^{\text {th }}$ and $19^{\text {th }}$ day respectively (fig. 15\&16). 
Figure 1

ACREMONIUM in AGP :

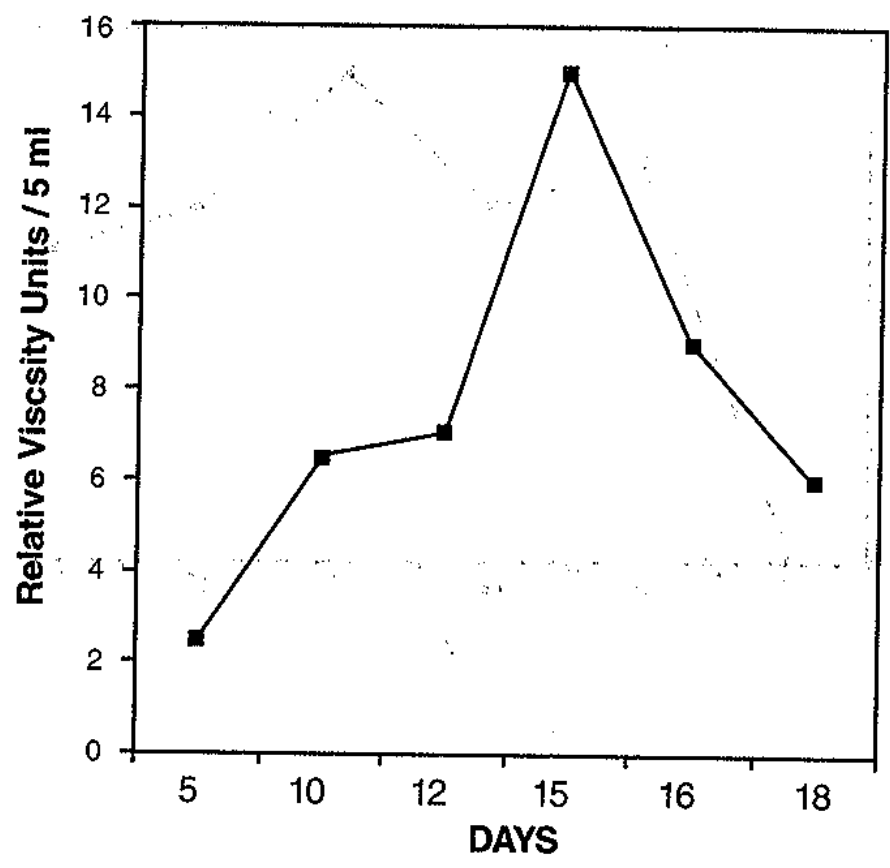

Figure 2

\section{C2 - NON SPORULATING WHITE COLONY PRODUCER IN AGP}

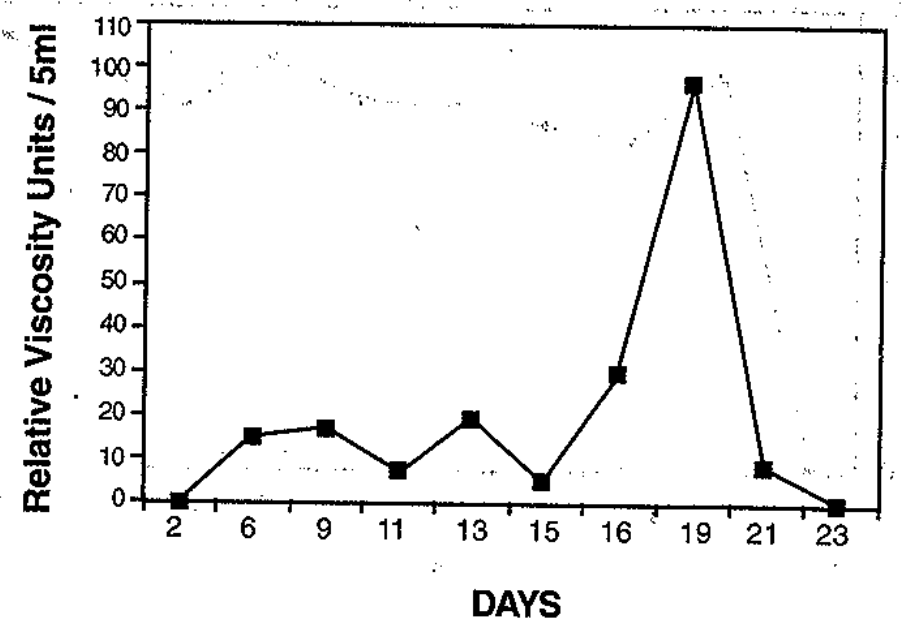


Figure 3

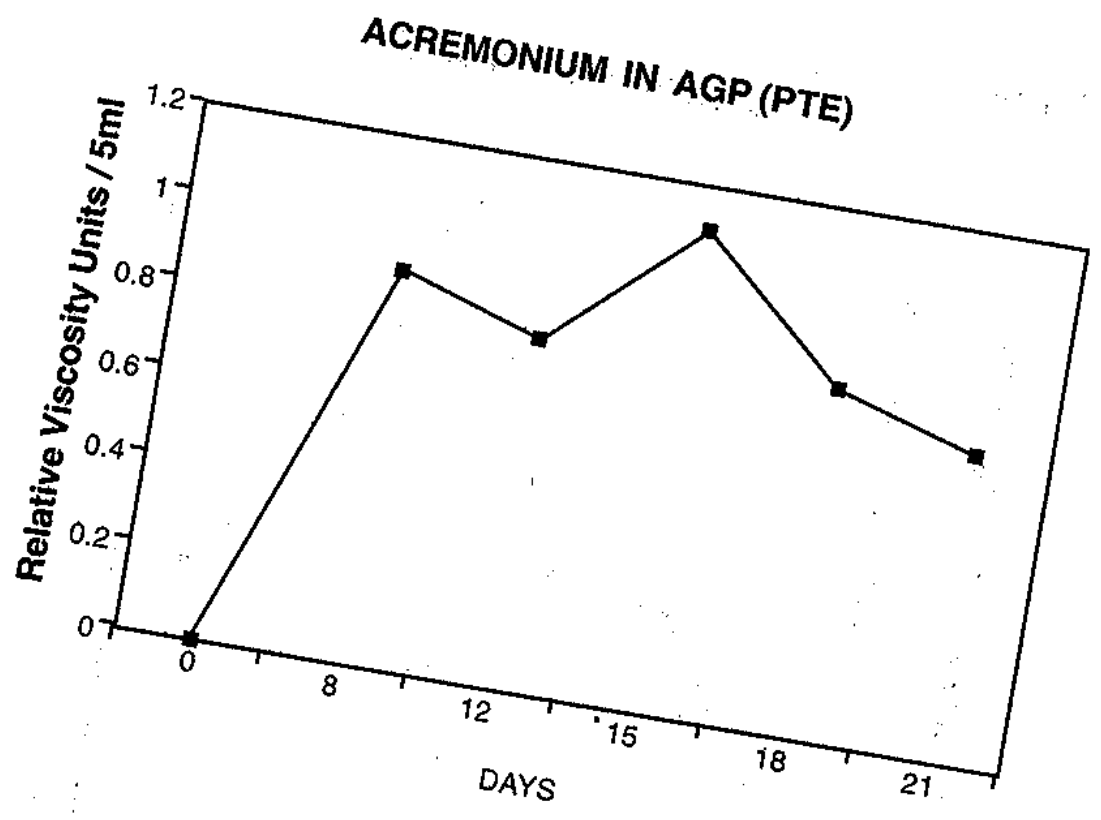

Figure 4

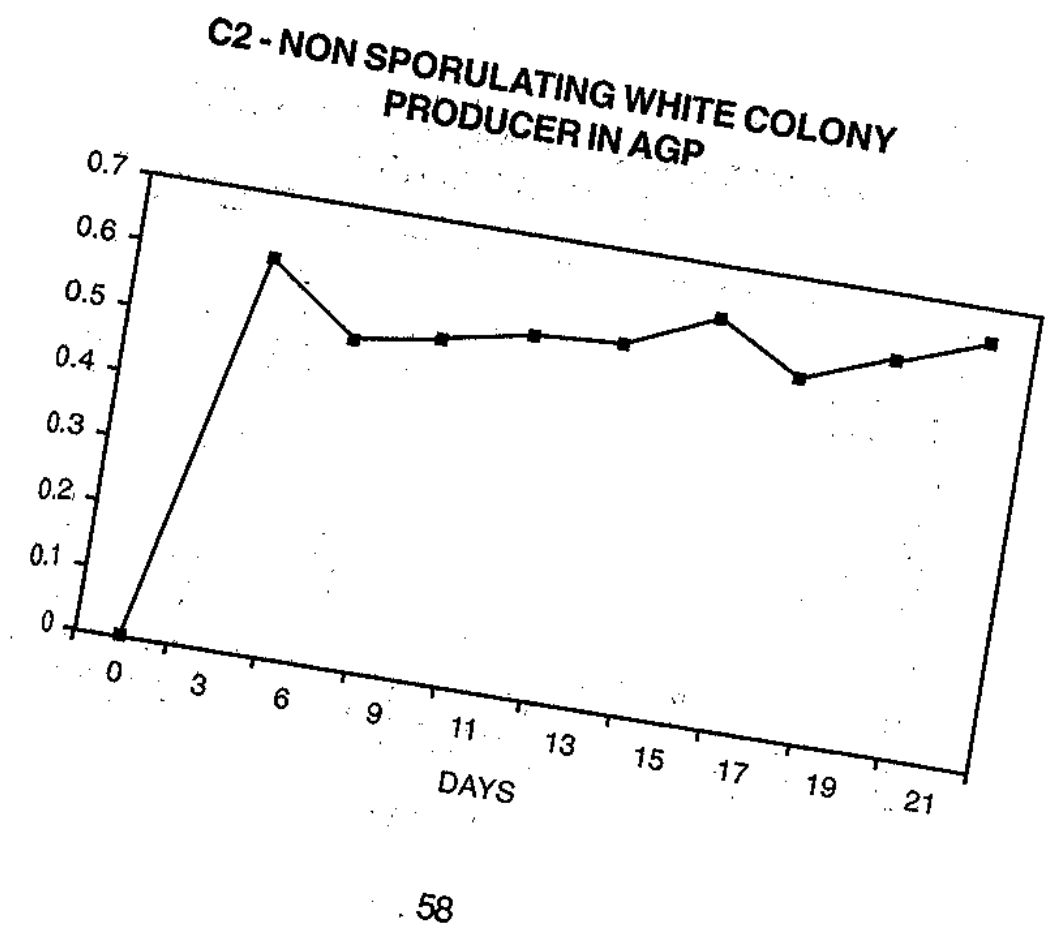


FIG. 5

ACREMONIUM IN CZ (STARCH) - AMYLASE ACTIVITY

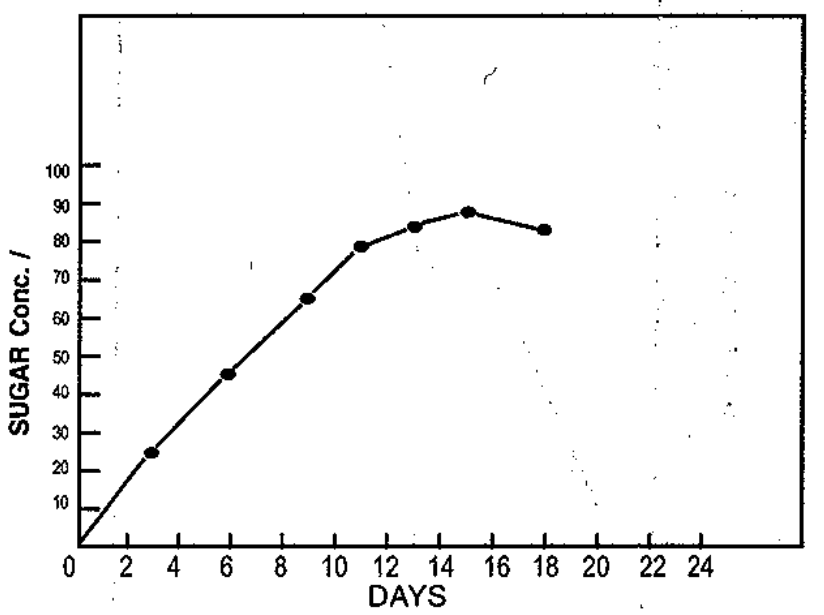

FIG. 6

ACREMONIUM IN CZ (STARCH) - INVERTASE ACTIVITY

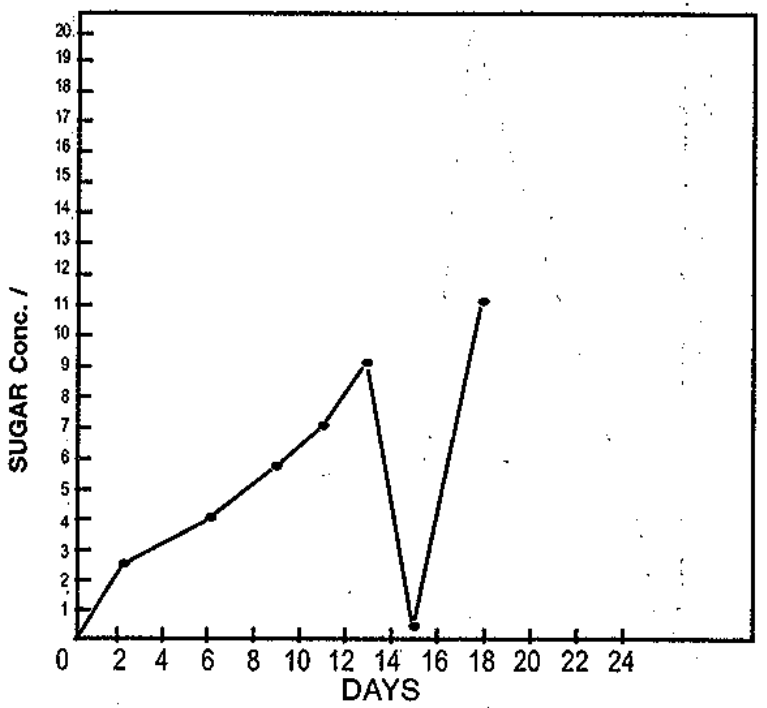

59 
FIG. 7

C2 - NON SPORULATING WHITE COLONY PRODUCER -

AMYLASE IN CZ (STARCH) ACTIVITY

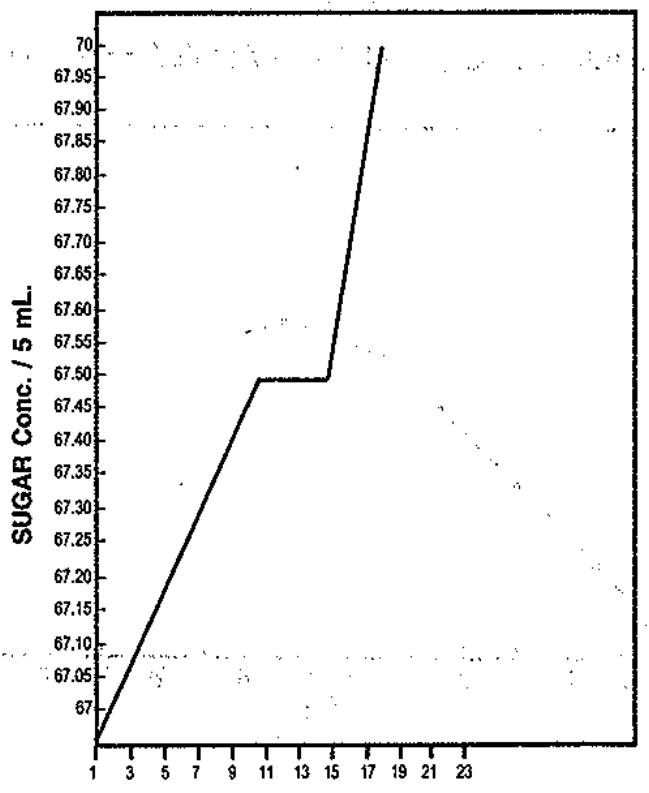

FIG. 8

C2 - NON SPORULATING WHITE COLONY PRODUCER - INVER IN CZ(STARCH) ACTIVITY

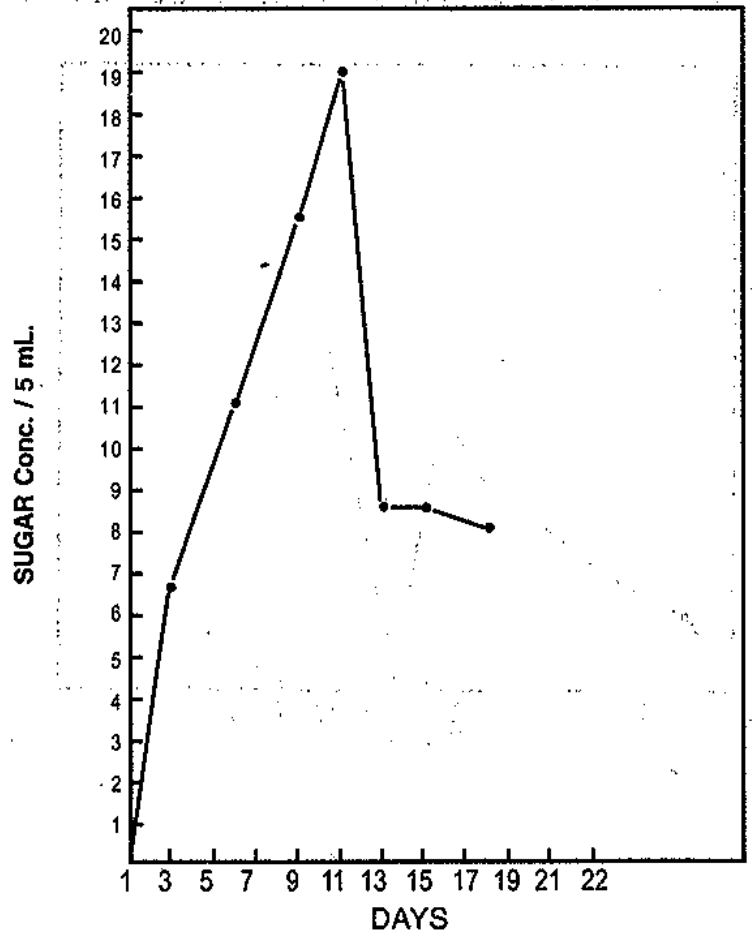


FiG. 9

ACREMONIUM IN CZ (CELLULOSE) - CELLULASE ACTIVITY

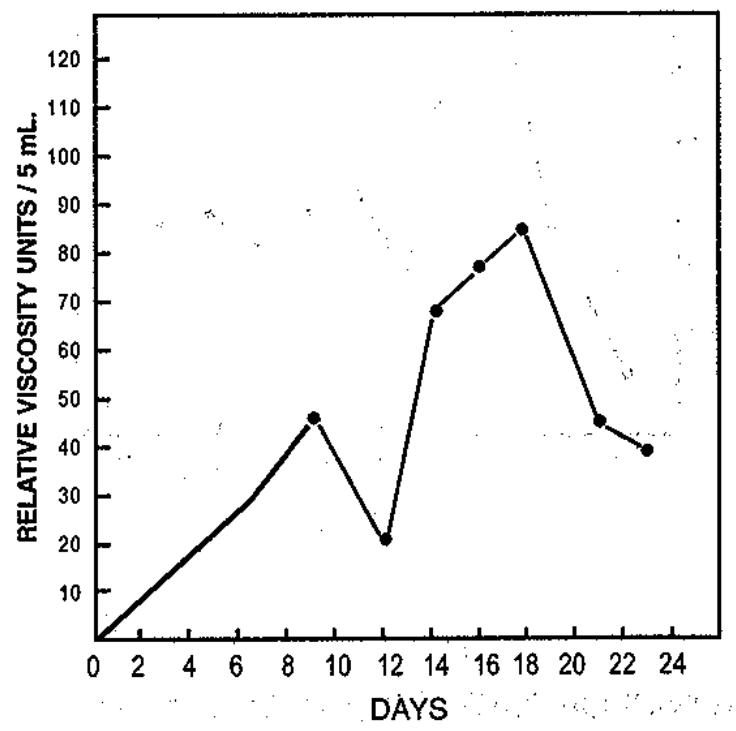

FIG. 10

C2 - NON SPORULATING WHITE COLONY PRODUCER -

CELLLULASE IN CZ (CELLULOSE) ACTIVITY

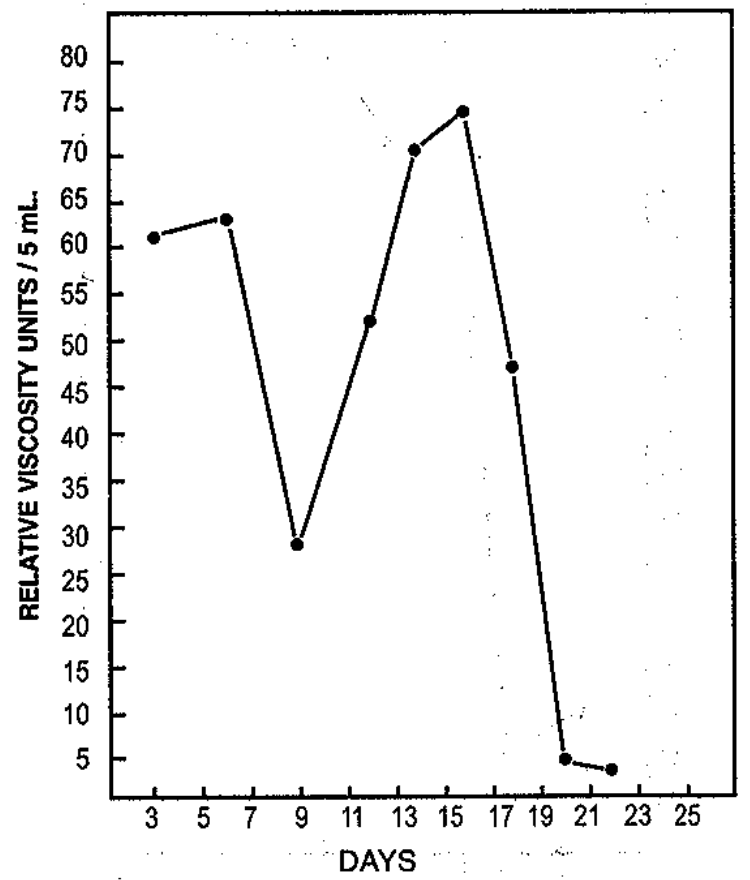


FIG. 11

NON-SPORULATING WHITE COLONY - pH PRODUCERIN CZ (CELLLULOSE)

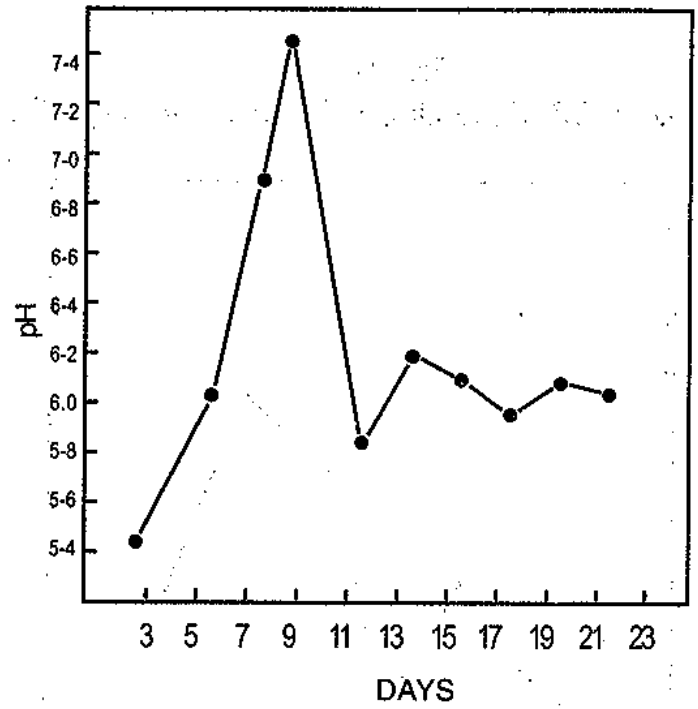

FIG. 11a

NON-SPORULATING WHITE COLONY - pH

PRODUCER IN AGP (PECTIN)

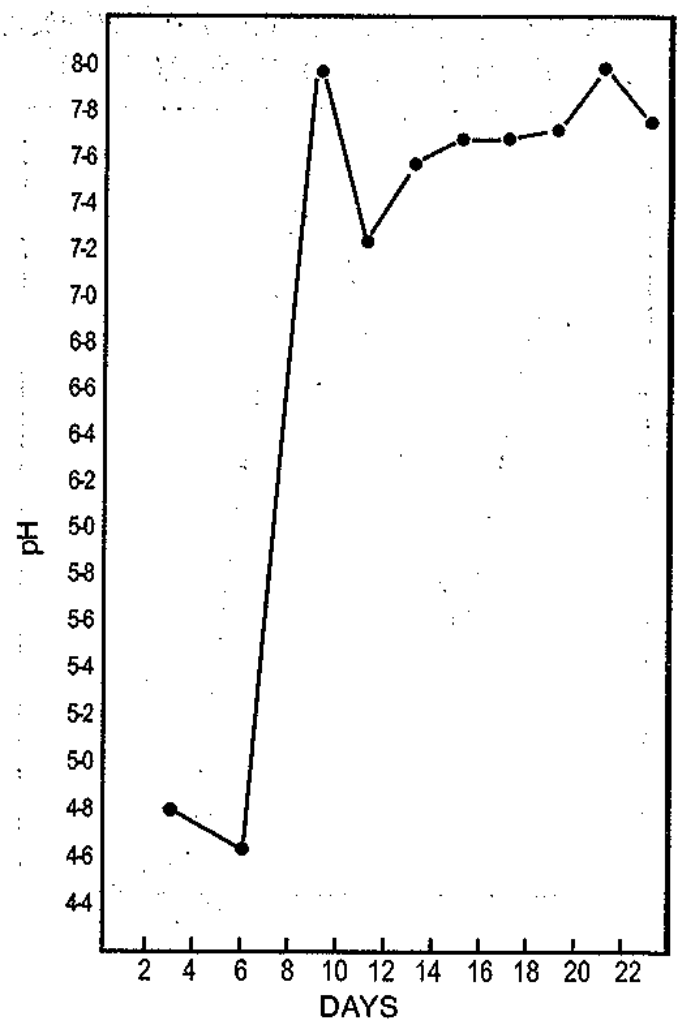


FIG. 12

ACREMONIUM IN CZ (CELLULOSE) - pH

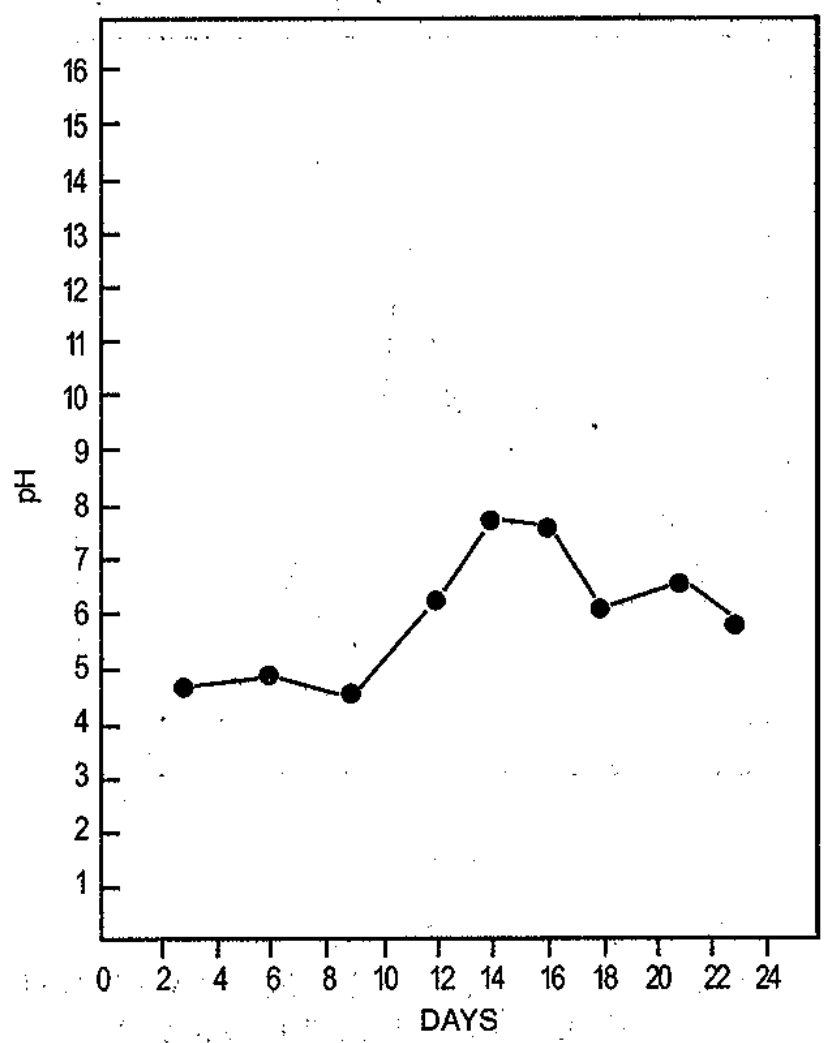

FIG. $12 a$

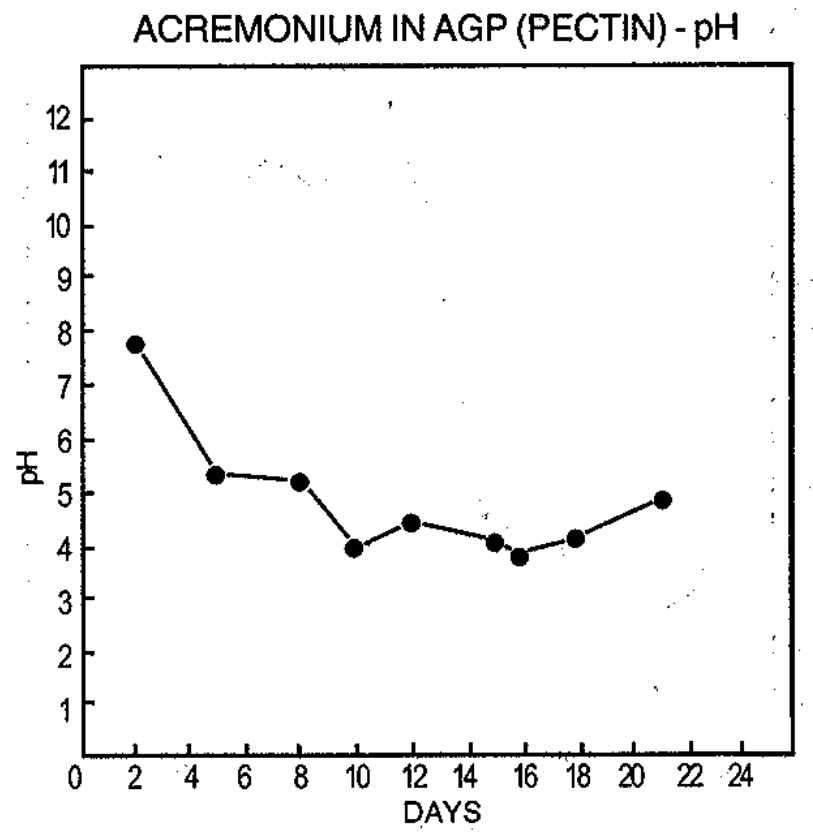


FIG. 13

ACREMONIUMIN CZ (CELLULOSE)-PROTEIN

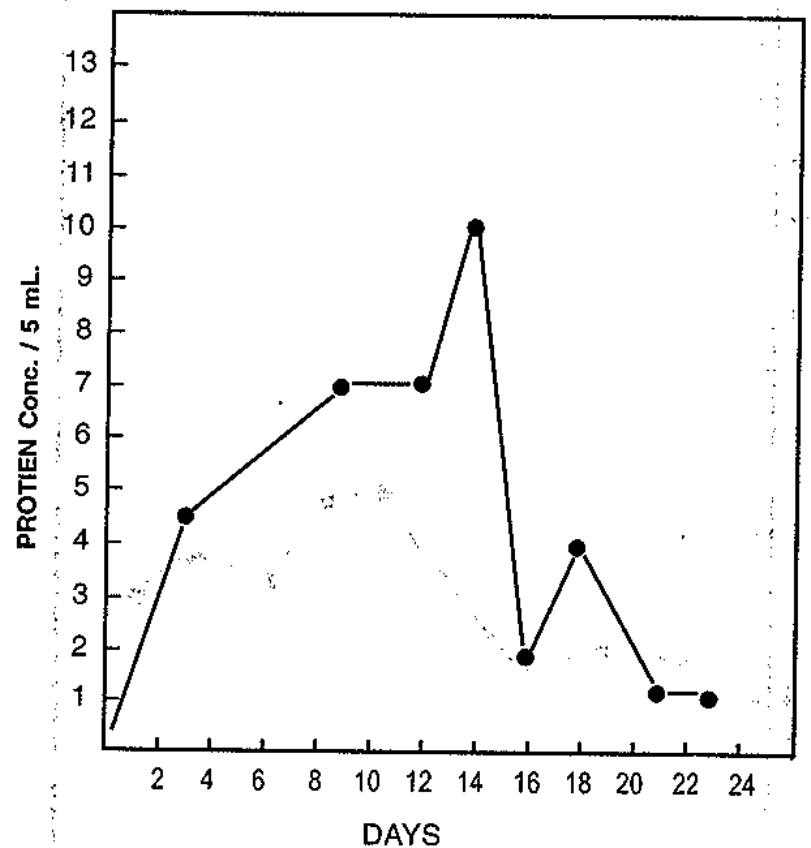

FIG. 14

NON-SPORULATING WHITE COLONY-PROTEIN PRODUCER IN CZ (CELLULOSE)

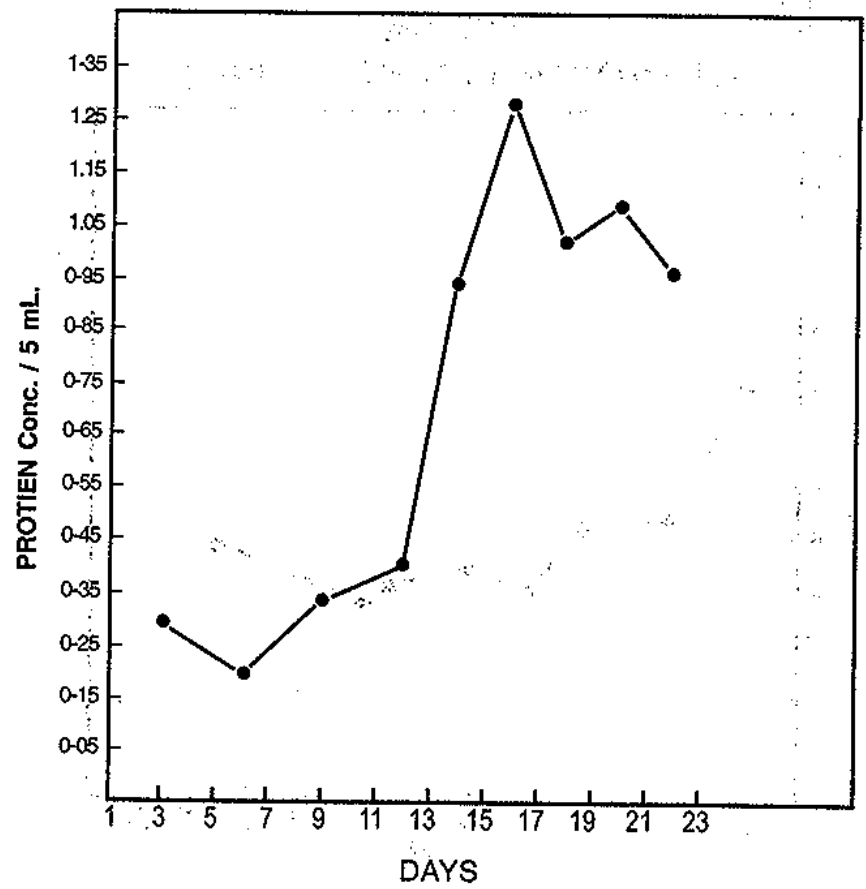


FIG. 15

ACREMONIUM IN AGP (PECTIN) - PROTEIN

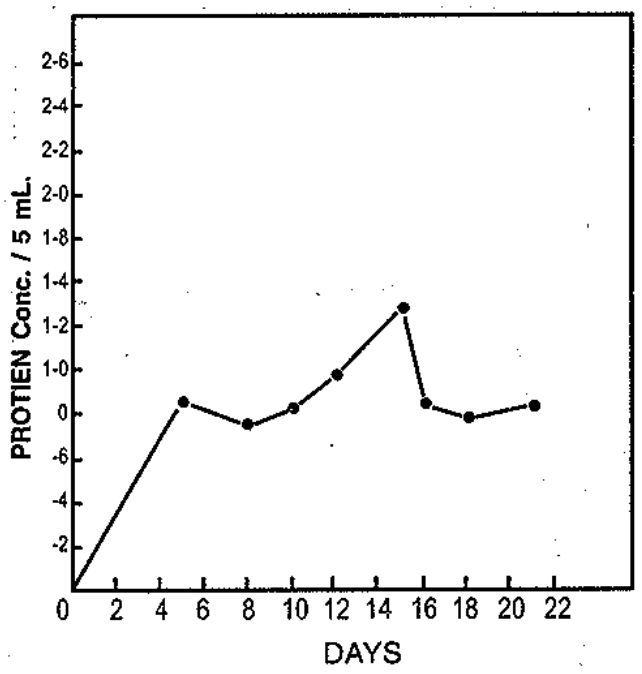

FIG. 16

NON-SPORULATING WHITE COLONY-PROTEIN PRODUCER IN AGP (PROTIN)

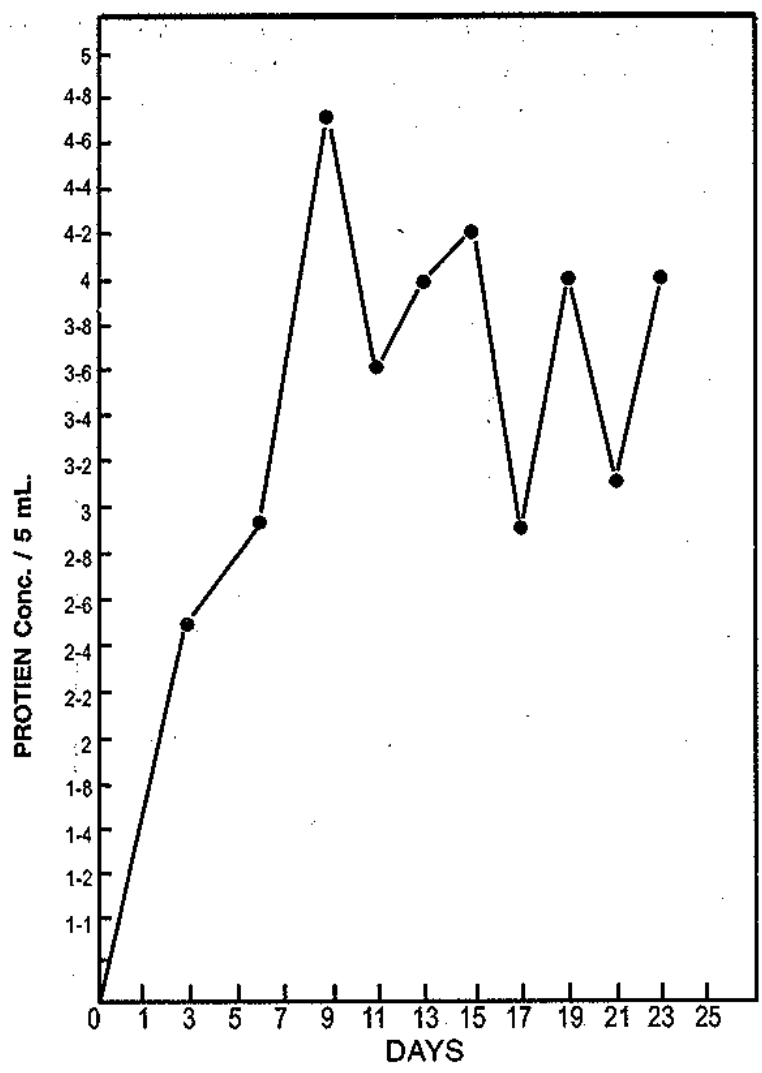


FIG. 17

ACREMONIUM IN CZ (CELLULASE) - MAT WEIGHT

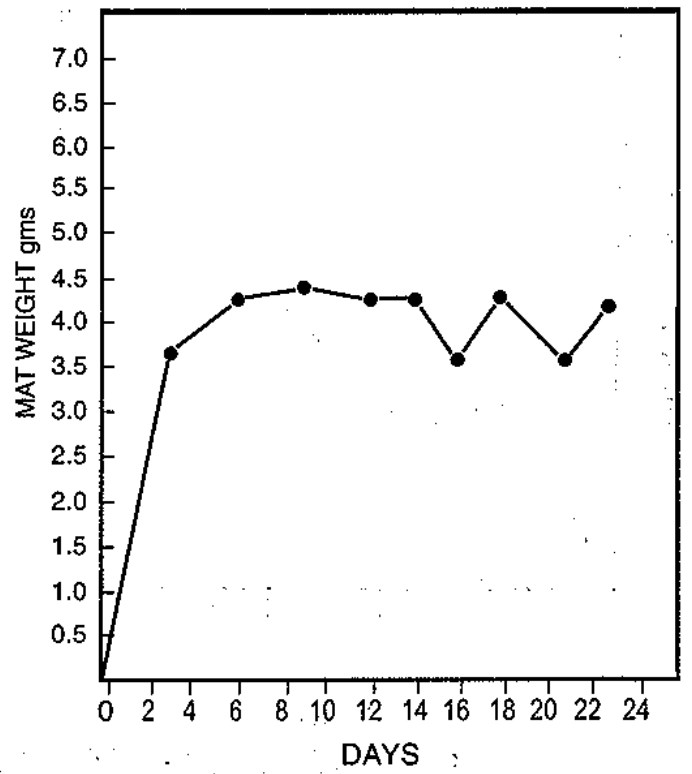

FIG. 18

NON-SPORULATING WHITE COLONY - MAT WEIGHT PRODUCER IN CZ (CELLULOSE)

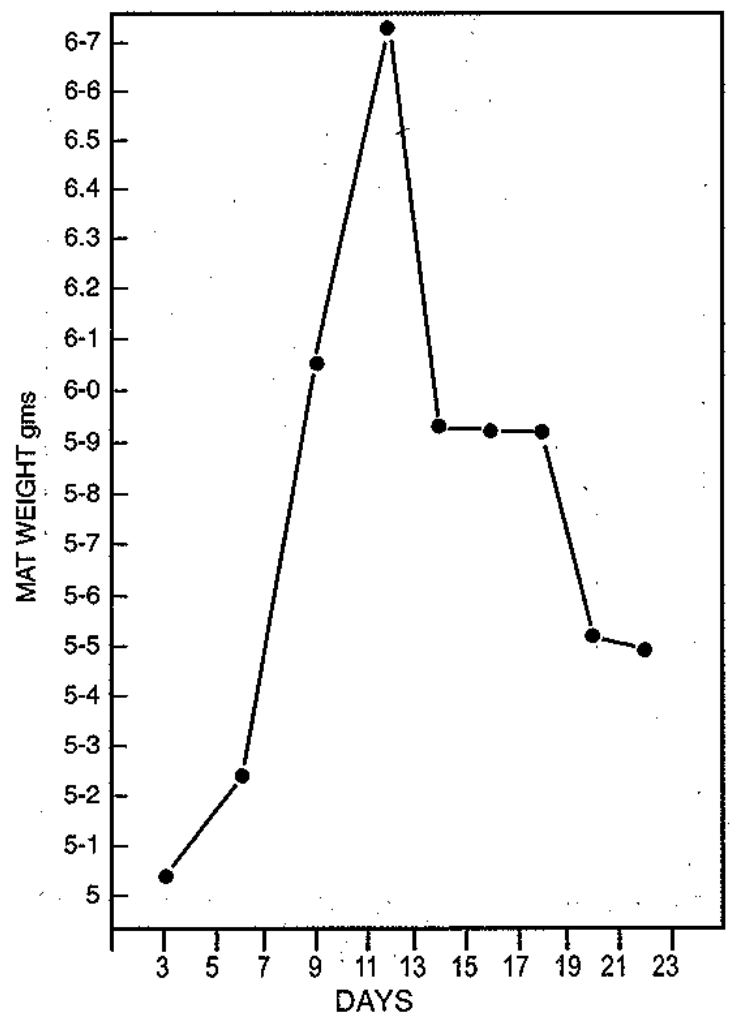


FIG. 19

ACREMONIUM IN AGP (PECTIN) - MAT WEIGHT

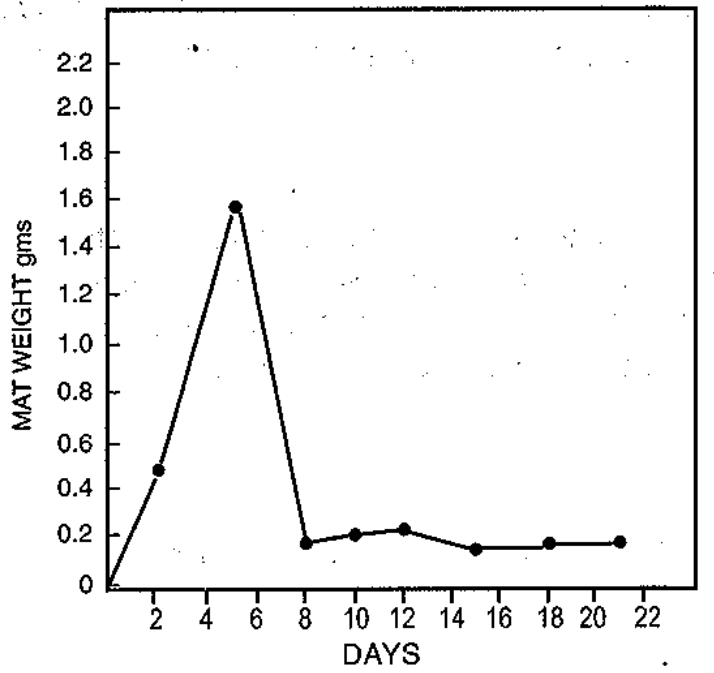

FIG. 20

NON-SPORULATING WHITE COLONY - MAT WEIGHT PRODUCERIN AGP (PECTIN)

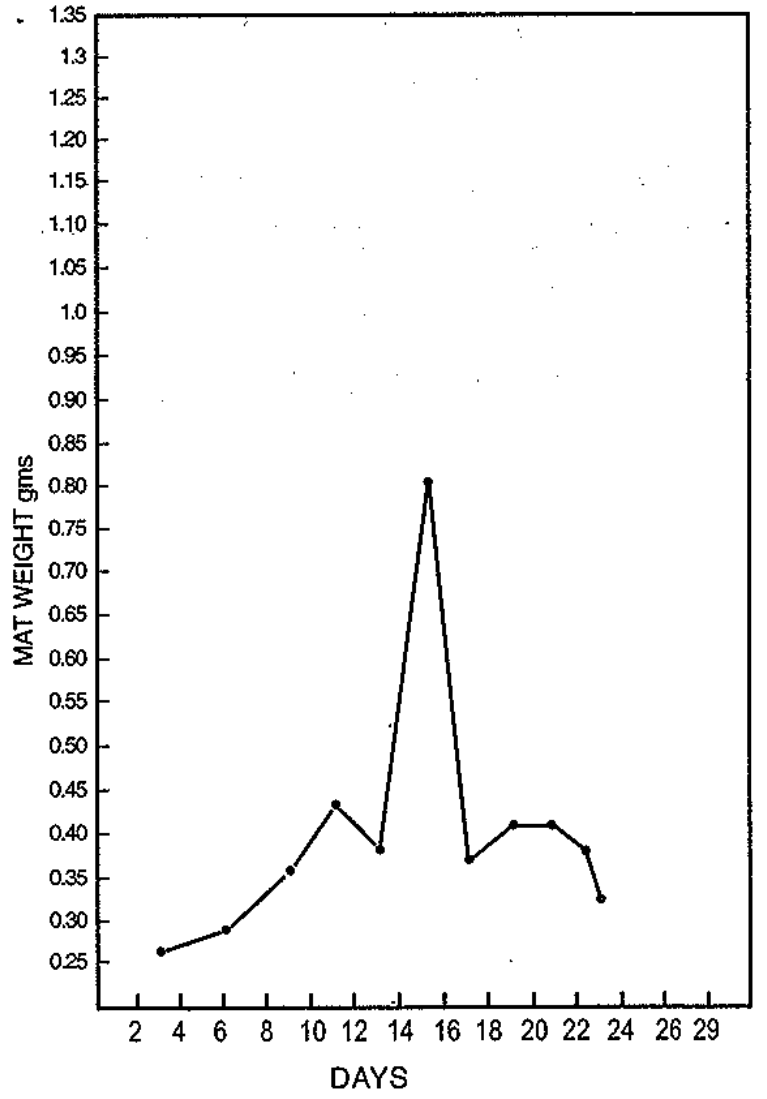




\section{Growth and mat weight}

Pectinase production was maximum when the $\mathrm{pH}$ was basic with both the fungi. On the $18^{\text {th }}$ day Acremonium sps. showed maximum growth and on the $11^{\text {th }}$ day the non-sporulating sps. (fig. 17\&18). On AGP medium the maximum growth was on the $5^{\text {th }}$ and $15^{\text {th }}$ day respectively (fig. 19\&20).

\section{Conclusion}

From the results it is clear that the fungi colonizing coffee litter produced a galacturonase like pectic enzyme which degrade the pectin present in the cell wall separating the cells so that they became more vulnerable to the action of other wall degrading enzymes.

\section{References}

1. Kaushik N.K., and H. B. N. Hynes. Arch. Hydrobiol. 1971. 68: $465-515$.

2. Kostalos, M., and R. L. Seymour., Oikos 1976. 27: 512-516.

3. Barlocher, F., and B. Kendrick. The fungai community: its organisation and role in the ecosystem. Marcel Derrer, Inc.; New York. 1981. P. $743-760$.

4. Ingold, C. T. An illustrated guide to Aquatic and fresh water borne Hyphomycetes (fungi imperfecti) and notes on Biology: Fresh water biological series. 1975 . No. $30-96$.

5. Lowry, O.H., J. Biol. Chem. 1951. 193: 265.- 275. 